\title{
Informal Work and the Implications for the Workers' Health: An Integrative Review
}

O Trabalho Informal e as Repercussóes para a Saúde do Trabalhador: Uma Revisão Integrativa El Trabajo Informal y las Implicaciones para la Salud de los Trabajadores: Una revisión integradora

Débora Cristina de Almeida Mariano Bernardino*; Marilda Andrade**

\begin{abstract}
Background: There are currently 127 million people working in informal conditions in Latin America and the Caribbean. Informal work is characterised by not ensuring access to basic social and labour rights, accentuating social inequalities.

Objectives: To identify the implications of informal work for the health of the workers in this sector of the economy. Methodology: Integrative literature review, conducted between December 2013 and February 2014.

Results: The study included 17 articles written in Portuguese, English or Spanish, available in the LILACS, MEDLINE and CINAHL databases.

Conclusion: In informal work settings, the workers are mostly affected by musculoskeletal system diseases and mental health problems. This type of work is a predominantly manual work, poorly paid, and not enough to meet the needs of the workers and their families, thus generating feelings of worthlessness and sometimes depression.
\end{abstract}

Keywords: Occupational health; working conditions; workers; health

\section{Resumo}

Enquadramento: Atualmente, 127 milhões de pessoas trabalham em condições de informalidade na América Latina e nas Caraíbas. O trabalho informal é marcado pela não-garantia de acesso a direitos sociais e laborais básicos, acentuando as desigualdades sociais.

Objetivos: Conhecer as repercussões do trabalho informal para a saúde dos trabalhadores inseridos neste setor da economia. Metodologia: Estudo de revisão integrativa da literatura, realizada entre os meses de dezembro de 2013 e fevereiro de 2014.

Resultados: Foram incluídos neste estudo 17 artigos redigidos em português, inglês ou espanhol, disponíveis nas bases de dados LILACS, MEDLINE e CINAHL.

Conclusão: Evidencia-se que, no contexto do trabalho informal, o trabalhador é acometido prevalentemente por complicações que afetam o sistema osteomuscular e a saúde mental. Decorrentes de um trabalho predominantemente braçal, mal remunerado, insuficiente para arcar com as necessidades do trabalhador $\mathrm{e}$ da sua família, gerando sentimento de inutilidade, e por vezes depressão.

Palavras-chave: Saúde do trabalhador; condições de trabalho; trabalhadores; saúde

\footnotetext{
Post-graduation, Health Sciences/ Nursing. Master's student, Sciences of Care. RN, Fluminense Federal University (UFF), School of Nursing Aurora de Afonso Costa (EEAAC), 24020091, Rio de Janeiro, Brasil [dcamariano@hotmail.com].Contribution to the article: Bibliographic search; data Janeiro, Brasil dcamariano@hotmail.com].Contribution to the article: Bibliographic search; data
collection, analysis and discussion; article writing. Address for correspondence: Avenida Carlos collection, analysis and discussion; article writing. Address for correspondence:
Meziano, No 482, Lote 01, Bloco 06 B, Apartamento 305, Portuguesa, Rio de Janeiro.

Meziano, No 482, Lote 01, Bloco 06 B, Apartamento 305, Portuguesa, Rio de Janeiro.
** Ph.D., Health Sciences/ Nursing. RN, Supervisor, Fluminense Federal Universitu (UFF), School of Nursing Aurora de Afonso Costa (EEAAC), 24020091, Rio de Janeiro, Brazil [marildaandrade@uol. com.br]. Contribution to the article: Substantial contribution to the data analysis and discussion and final revision of the article.
}

\section{Resumen}

Marco contextual: En la actualidad, 127 millones de personas trabajan en condiciones informales en América Latina y el Caribe. El trabajo informal se caracteriza por no garantizar el acceso a los derechos sociales y laborales básicos, lo que acentúa las desigualdades sociales.

Objetivos: Conocer el impacto del trabajo informal para la salud de los trabajadores incluidos en este sector de la economía.

Metodología: Estudio de revisión integradora de la literatura, llevado a cabo entre los meses de diciembre de 2013 hasta febrero de 2014.

Resultados: El estudio incluyó 17 artículos escritos en portugués, inglés o español, disponibles en las bases de datos LILACS, MEDLINE y CINAHL.

Conclusión: Podemos ver que en el contexto del trabajo informal, el trabajador se ve afectado principalmente por complicaciones que afectan al sistema músculo-esquelético y a la salud mental, que derivan de un trabajo predominantemente manual, mal remunerado, insuficiente para hacer frente a las necesidades de los trabajadores y sus familias, lo que genera sentimientos de inutilidad y, a veces, depresión.

Palabras clave: Salud laboral; condiciones de trabajo; trabajadores; salud

Received for publication: 23.06 .14 Accepted for publication: 30.04 .15 


\section{Introduction}

Informal work can be defined as an employment relationship that does not comply with tax payment and is not covered by social security, lacking work benefits (Organización Internacional del Trabajo [OIT], 2013a).

However, there is another form of connotation of informal work, which involves including employees without a formal contract, self-employed workers who do not contribute to social security, unpaid workers and workers involved in construction for personal use and production for self-consumption in this group (Krein, Cardoso, Biavaschi, \& Texeira, 2013).

There are currently 127 million people working in informal conditions in Latin America and the Caribbean (OIT, 2013a).

According to Costa (2010), informality is marked by the precariousness of the working and living conditions, as well as by the denial of the most basic principles of citizenship, accentuating social inequalities. This statement is based on peculiarities inherent to informal work.

In Brazil, as well as in developing countries in general, a large part of the active population works in the informal sector. In this scenario, we find authoritarian relationships, with the prevalence of a lack of security, poor quality medical care, poverty, hunger and exploitation. The latter is usually translated into long working days, very low paid jobs and a lack of access to basic social and labour rights (Matsuo, 2009).

In an analysis carried out on the evolution of the informal sector in Brazil, Mattoso (as cited in Costa, 2010) argues that the 1990s were a historic milestone as regards the reconfiguration of the world of work. Structural and economic changes in the country have resulted in an increase of precarious forms of work on a large scale. About 3.3 million formal jobs were extinct.

For most of the workers dismissed, informality represented an opportunity to remain in the world of work. The population is now obtaining the source of income in professional activities defined as informal, which include several modalities: Street vendors, car vigilantes on the streets, garbage scavengers, human billboards, casual domestic workers, among others (Costa, 2010).

Recently, the International Labour Organization said that
Latin America and the Caribbean is still the world's most unequal region, and this is largely due to the fact that the majority of the employed population works in the informal economy, which reduces the capacity to generate income, perpetuating the cycles of poverty. (OIT, 2013b, p.45)

In support of this idea, Sobral and Freitas (2010) refer that the social strata influence the differentials of exposure and vulnerability to the risks of health damage in the form of diseases or accidents, and, consequently, the health status of the populations. In this way, we can infer that informal workers, who share the same occupational insertion characteristics, as well as the same social prestige and wealth, represented respectively by education and income, are in a situation of vulnerability because they are in a less favourable social position.

In light of the above, it is important to develop integrative review studies that address the implications of informal work for the health of the population in this sector of the economy. These studies, with the aim of showing to the public the reality of health and working conditions of informal workers, make it possible to propose new measures for health promotion, protection, and recovery of these workers, taking into account all their specificities.

The objective of this study was to identify the implications of informal work for the health of the workers employed in this sector of the economy, by gathering scientific articles published between 1990 and 2014 on this issue. With the purpose of achieving the proposed objective, the following question was formulated: What are the health conditions of individuals working in informal economy identified in the scientific literature published between 1990 and 2014 ?

\section{Methodological Procedures of the Integrative Review}

The methodology used to achieve the objective proposed for this study was the integrative literature review, which aims at understanding a specific topic based on other independent studies, by means of the systematisation and analysis of results. The study was conducted in six stages: Identification of the theme; literature review; categorisation of studies; assessment of the studies included in the integrative 
review; interpretation of results; and presentation of the review (Ganong 1987, as cited in Santos and Hormanez, 2013).

Data were collected between December 2013 and February 2014. The inclusion criteria of the articles selected for this study were: Observational studies, clinical trials, quasi-experimental, descriptive, exploratory and ethnographic studies, with either a quantitative or a qualitative approach. The studies had to have been published between 1990 and 2014 in Portuguese, English or Spanish, free of charge, in fulltext, in the following electronic databases: LILACS, MEDLINE, CINAHL and Cochrane. The time limit is justified by the fact that the year 1990 is considered a historic milestone as regards the reconfiguration of the world of work in Brazil and, therefore, there was a significant increase of populations that began to obtain their source of income through professional activities defined as informal.

The search excluded articles which did not mention or were unclear as to the employment relationship of the research subjects, i.e. this review only included studies with subjects who were considered informal workers. Thus, the articles included addressed employees without a work contract, non-taxpayers self-employed workers, unpaid workers and workers involved in construction for personal use and production for self-consumption.

In LILACS, the following Health Sciences Descriptors (DeCS) were used:Occupational Health and Working Conditions and Workers - category SP3.056.092. The use of this last descriptor is justified by the lack of an expression that would more specifically represent informal workers in the structured and trilingual DeCS vocabulary, being, therefore, the word workers used as a synonym of informal workers in the set of Health Sciences Descriptors. In the search performed, a total of 1479 matches were identified. Of these, 532 were selected as potential eligible articles for this review. After reading the abstract of all articles, 12 of them were included in the study.

In MEDLINE, the following MeSH terms were used: Occupational Health and Health Status, with the descriptor Working Conditions. The search retrieved
2562 publications. After reading the abstracts of all studies, 108 articles were selected. Of these, two were repeated in the LILACS database and had to be excluded. Only three articles were included in the review.

In CINAHL, the following titles were used: Occupational Health and Health Status. A total of 785 matches were identified. Of these, 64 were selected after abstract reading, and only two articles were included.

In Cochrane, six publications were found based on the following MeSH terms: Occupational Health and Health Status. However, none of the articles was related with the theme of the study, thus none of the articles were selected/included in this review.

Therefore, of the 704 articles selected based on abstract reading, and considering the inclusion and exclusion criteria established for the search, 17 articles were used in this integrative review for being relevant to the proposed study. These data can be seen in detail in Table 1.

To better describe the methodological procedures of the integrative review, we highlight that, after gathering all matches resulting from the search using DeCS and MeSH terms, the existing filters were associated with the searched databases. From then on, all abstracts were read and the articles with the potential to be included in this integrative review were selected according to the pre-established inclusion and exclusion criteria. Subsequently, all articles were carefully read, with the purpose of identifying the studies which would be included in this review. A form was used in the categorisation and evaluation of the articles which aimed to summarise the studies that answered the research question, identify the title of the articles, the study type, the year of publication, the journals where they were found, the country where they were conducted, and the major aspects related to the health conditions of informal workers. The results were presented using descriptive and graphic methods, with the purpose of gathering the evidence related to the health and working conditions of informal workers. 
Table 1

Distribution of the references found in the LILACS, MEDLINE, CINAHL and Cochrane databases between 1990 and 2014

\begin{tabular}{lcccc}
\hline Database & Articles found/matches & Articles selected & Articles repeated & Articles included \\
\hline LILACS & 1479 & 532 & - & 12 \\
MEDLINE & 2562 & 108 & 2 & 3 \\
CINAHL & 785 & 64 & - & 2 \\
Cochrane & 6 & 0 & - & 0 \\
\hline
\end{tabular}

Note. Data obtained through searches in the abovementioned databases.

\section{Results and Interpretation}

Of the 17 articles published on the topic under analysis, nine (53\%) had been developed in Brazil; three $(17.6 \%)$ in Colombia; and two $(11.7 \%)$ in India. In Honduras, Peru and in the United States of America, only one study was conducted, i.e. each one of these countries contributed with $5.8 \%$ of the total of studies included in this review. All of the studies included complied with the ethical and legal principles of research involving human subjects.

Regarding the year of publication, the study searched for articles published between 1990 and 2014. However, none of the articles had been published until 2001. In 2002, only one article was published and in 2004 two articles were published. Between 2007 and 2013, 14 articles were published. In relation to the methodology used in the articles analysed in this study, we observed that ten (59\%) of these are observational studies; four (23.2\%) are descriptive and exploratory studies; two (11.8\%) are descriptive studies and one is an (5.9\%) ethnographic study. According to the data on the health conditions of informal workers illustrated in the studies analysed, we observed that 14 (82.3\%) of the 17 articles reported musculoskeletal problems as being one of the main health problems among the research subjects. The presence of pain in the legs, arms, shoulders, back, spine, knees and tendinitis was frequent. In the same way, we found that informal workers suffered from mental health problems. Of the 17 studies, six (35.2\%) pointed out problems related to the mental health of the sampled subjects, including stress, anxiety, insomnia, alcoholism, loss of self-esteem, feeling of inferiority, insecurity, helplessness.

Table 2 summarises the studies included in this integrative review, indicating the title and the authors of the articles, the type of study, the year, the database in which they were published, the country where they were developed, and the major aspects related to the health conditions of informal workers.

Table 2

Summary of the studies included in the Integrative Review

\begin{tabular}{|c|c|c|c|c|c|}
\hline Title / reference & Type of study & Year & Database & Country & Major health-related aspects \\
\hline $\begin{array}{l}\text { Almeida,J. R., Elias, E. T., Magalhães, M., \& Vieira, } \\
\text { A. J. (2009). Efeito da idade sobre a qualidade de } \\
\text { vida e saúde dos catadores de materiais recicláveis } \\
\text { de uma associação em Governador Valadares, Minas } \\
\text { Gerais Brasil. Ciências e Saúde Coletiva, } 14(6) \text {, } \\
\text { 2169-2180. Retrieved from http://www.scielo.br/ } \\
\text { scielo.php?script=sci_pdf=S141381232009000 } \\
\text { 600024\&lng=en\&nrm=iso\&tlng=pt }\end{array}$ & Observational & 2009 & LILACS & Brazil & $\begin{array}{l}\text { Pain was frequent in all age groups } \\
\text { of garbage collectors, with a higher } \\
\text { incidence of headache, leg pain } \\
\text { and back pain. }\end{array}$ \\
\hline $\begin{array}{l}\text { Porto, M. F. S.; Juncá, D. C. M.; Gonçalves, R. S \& Filhote, } \\
\text { M.I. F. (2004). Lixo, trabalho e saúde: um estudo de } \\
\text { caso com catadores em um aterro metropolitano no } \\
\text { Rio de Janeiro, Brasil. Caderno Saúde Pública, } 20 \text { (6), } \\
\text { 1503-1514. Retrieved from http://www.scielo.br/scielo. } \\
\text { php?script = sci_nlinks\&ref=000185\&pid=S0102- } \\
7182200600020000900023 \& \operatorname{lng}=\text { pt }\end{array}$ & $\begin{array}{l}\text { Descriptive/ } \\
\text { Exploratory }\end{array}$ & 2004 & LILACS & Brazil & $\begin{array}{l}\text { Pain and osteoarticular problems; } \\
\text { high blood pressure; respiratory } \\
\text { disorders; varices; worms; aller- } \\
\text { gies and skin problems are usually } \\
\text { reported by the workers. }\end{array}$ \\
\hline
\end{tabular}


Prazeres, T. J., \& Navarro, V. L. (2011). Na costura do sade trabalho e saúde das pespontadeiras da indústria de calçados de Franca, São Paulo, Brasil. Cad. Saúde Pública, 27(10),1930-1938. Retrieved from http://www.scielo.br/ $\mathrm{pdf} / \mathrm{csp} / \mathrm{v} 27 \mathrm{n} 10 / 06 . \mathrm{pdf}$ pato, o desmanche das operárias: estudo das condições

The most frequent complaints of the interviewees were: finger, hand, arm, shoulder, knee, leg,

Descriptive/ 2011 LILACS Brazil foot, and back pain.

Exploratory 2011 LILACS Brazil Psychic suffering together with the inadequate work conditions make the workers even more vulnerable to becoming ill.

Symptoms such as stress, insomnia, fatigue, constipation, loss of

Costa, D. O., \& Tambellini, A. T. (2009). A visibilidade dos escondidos. Physis Revista de Saúde Coletiva, 19 (4), 953-968. Retrieved from http://www.scielo.br/pdf/physis/ v19n4/v19n4a03.pdf self-esteem, tachycardia, back pain, tendinitis, feeling of inferiority and insecurity were reported by the research subjects.

Díaz, J. M., Abril, F. G., \& Garzón, J. A. (2010). Salud y trabajo: Minería artesanal del carbón en Paipa, Colombia. Avances en Enfermería, 28(1), 107-115. Retrieved from http://bases.bireme.br/cgibin/wxislind.exe/iah/ online/?IsisScript $=$ iah $/$ iah. $. x i s \& s r c=$ google\&base $=$ LILA

Observational 2010 LIACS Colom- Osteoarticular diseases are present bia in the sampled population.

CS\&lang $=p \&$ nextAnextA $=$ lnk\&exprSearch $=561944 \& \mathrm{i}$ ndexSearch $=$ ID

Ballesteros, V. L., Arango, Y. L., \& Urrega, Y. M. (2012).

Condiciones de salud y de trabajo informal en recuperadores ambientales del área rural de Medellín, Colombia, 2008. Revista de Saúde Coletiva, 46(5), 866-874. Re-

Colom- Overall, the main morbidities trieved from http://pesquisa.bvsalud.org/dss/resources/ lil-655039

Alencar, M. C., Cardoso, C. C., \& Antunes, M. C. (2009). Condições de trabalho e sintomas relacionados à saúde de catadores de materiais recicláveis em Curitiba. Revista de Terapia Ocupacional da Universidade de São Paulo, 20(1), 36-42. Retrieved from http://pesquisa.bvsalud.org/ portal/resource/pt/lil-657211
Observational 2012 MEDLINE Colom- identified were: Musculoskeletal, respiratory and stress problems.
Lakhani, R. (2004). Occupational health of women construction workers in the unorganised. Journal of Health Management, 6(2), 187-200. Retrieved from http://hhm.sagepub.com/content/6/2/187.full.pdf. doi: 10.1177/0972063404006002

The following symptoms were prevalent: Musculoskeletal pain, physical fatigue, headache, gastritis

Descriptive / 2009 LILACS Brazil (36.4\%), insomnia, concentration difficulties, mood swing, low selfesteem, helplessness, anxiety and humiliation.

There was a prevalence of respiratory diseases, musculoskeletal problems and psychiatric disorders. The study concluded that these impairments are related to the nature of the work and the instability of the job due to its informal nature.

Gangopadhyay, S., \& Das, T. (2012). An ergonomic study on the onset of mental fatigue among the load handling workers of a central market area in Kolkata. Work: A Journal of Prevention, Assessment and Rehabilitation, 41(0), 2467-2471. Retrieved from http://pesquisa. bvsalud.org $/$ portal $/$ output $=$ site\&lang $=p t \&$ from $=0 \&$ sort $=\&$ format $=$ summary $\&$ cococ $=20 \& f b=\&$ page $=$ 1\&filter\%5Bdb\%5D\%5B\%5D=LILACS\&q = An + ergon omic + study + on + the + onset + of + mental + fatigue t among + the + load + handling + workers + of + a + central + market + area $+\mathrm{ii}+$ Kolkata\&index $=$ ti\&sear ch_form_submit = Pesquisar

Milían, L. C., Rivera, M. F., \& Chévez, F. M., (2011).

Pobreza, salud y trabajo en cultivadores de tabaco en el valle de Jamastrán, El paraíso, Honduras. Rev. Med Hondur, 79, (4), 191-196. Retrieved from http://www.bvs. hn/RMH/pdf/2011/pdf/Nol79-4-2011-5.pdf
Observational 2004 CINAHL India
Around $91 \%$ of the workers scored less than 50 on a scale from 0 to 100 concerning their physical Observational 2012 CINAHL India health status. Likewise, the mental health index was also not satisfactory since $57 \%$ of the respondents scored below 50
Vigil, L., Gutiérrez, R., Cáceres, E., Collantes, H., \& Beas, J. (2007). Salud ocupacional del trabajo de estiba: Los trabajadores de mercados mayoristas de Huancayo. Revista Peruana de Medicina Experimental y Salud Publica, 24(4), 336-342. Retrieved from http://www. scielo.org.pe/scielo.php?script $=$ sci pdf\&pid $=$ S1726$46342007000400003 \& \operatorname{lng}=$ es\&nrm =iso\&tlng =es

\section{Hondu- tion under study: osteoarticular}

pain $(77.5 \%)$, migraine $(56.3 \%)$, skin irritation (50\%), fever (48.8\%), diarrhoea (48.8\%), cough/sneezing (47.5\%).

Complaints such as shoulder skin thickening $(80.9 \%)$, dorsal hyperciphosis (62\%), low back pain (55\%), pterygium (13.3\%) and neck pain (11.4\%) were reported by the population under study as a result of inadequate posture at work. 
Bazo, M. L., Sturion, L., \& Probst. V. S., (2011). Caracterização do reciclador da ONG RRV em Londrina-Paraná. Rev. Fisioter Mov, 24(4), 613-20. Retrieved from http:// www.scielo.br/pdf/fm/v24n4/04.pdf

Of the sampled recycling workers, $22 \%$ had high blood pressure and heart diseases and 39\% migraine.

Observational 2011 IIIACS Brazil All recycling workers reported musculoskeletal pain and there was a statistically significant increase of pain in the upper limbs after the beginning of the work activities.

Prosenewicz, I., \& Lippi, U. G. (2012). Acesso aos serviços de saúde, condições de saúde e exposição aos fatores de risco: Percepção dos pescadores ribeirinhos do Rio Machado de Ji-Paraná, RO. Saúde Sociedade, 21(1), 219-31. Retrieved from http://www. scielo.br/scielo.php?script $=$ sci_pdf\&pid $=$ S0104$12902012000100021 \& \operatorname{lng}=$ en\&nrm $=$ iso\&tlng $=p t$

Rosa, M. F., \& Matos, U. A. (2010). A saúde e os riscos dos pescadores e catadores de caranguejo da Baía de Guanabara. Ciências e Saúde Coletiva, 15(1), 1543-1552. Retrieved from http://pesquisa.bvsalud.org/portal/ resource/pt/lil-555689

Jaimes, C. P., \& Amaya, R. M. (2013). Condiciones de salud y laborales de la población trabajadora informal en situación de desplazamiento de Bucaramanga, Colombia. Investigaciones Andina, 15(26), 628-639. Retrieved from http://pesquisa.bvsalud.org/portal/resource/pt/ lil-673613. doi: 10.3233/WOR-2012-0482-246
The fishermen who participated in this study reported the following symptoms: back pain, leg pain, muscle pain, cramps, visual problems, headache, flew, skin diseases Problems in the joint and neuromuscular system were frequent. They may be related to the long Descriptive / 2010 MEDLINE Brazil day of work and the weight overExploratory $2010 \quad$ Brazil load, which are common in their work activities.

\begin{tabular}{|c|c|c|c|c|c|}
\hline $\begin{array}{l}\text { Walter, N., Bourgois, P., Loinaz, M., \& Schillonger, D., } \\
\text { (2002). Social Context of word Injury Among Undocu- } \\
\text { mented Day Laborers in San Francisco.J. Gen. Intern. } \\
\text { Med, } 17 \text { (4), 221-229. Retrieved from http://www.ncbi. } \\
\text { nlm.nih.gov/pmc/articles/PMC1495019/pdf/jgi_10501. } \\
\text { pdf }\end{array}$ & $\begin{array}{c}\text { Ethnographic } \\
\text { study }\end{array}$ & 2002 & MEDLINE & USA & $\begin{array}{l}\text { Muscle and bone injuries with } \\
\text { acute and chronic pain were the } \\
\text { most common symptoms among } \\
\text { the group of workers in this study. } \\
\text { Burns, lacerations and fractures are } \\
\text { not rare. Dermatitis, resulting from } \\
\text { activities using abrasive materi- } \\
\text { als without gloves, dust-related } \\
\text { chronic allergic conjunctivitis, } \\
\text { anxiety, depression and drug abuse } \\
\text { were also reported. }\end{array}$ \\
\hline $\begin{array}{l}\text { Ferreira, Lucille Ribeiro, Pinheiro, Tarcísio Márcio Mag- } \\
\text { alhães, Siqueira, Arminda Lucia, \& Carneiro, Ana Paula } \\
\text { Scalia. (2008). A silicose e o perfil dos lapidários de } \\
\text { pedras semipreciosas em Joaquim Felício, Minas Gerais, } \\
\text { Brasil. Cadernos de Saúde Pública, 24(7), 1517-1526. } \\
\text { Retrieved October 29, 2015, from http://www.Scielo.br/ } \\
\text { scielo.php?script=sci_arttext\&pid=S0102-311X2008000 } \\
\text { 700006\&lng=en\&tlng=pt. }\end{array}$ & Observational & 2008 & LILACS & Brazil & $\begin{array}{l}\text { Gem cutters had respiratory diseas- } \\
\text { es. The study concluded that the } \\
\text { morbidities reported are positively } \\
\text { related to the exposure to occu- } \\
\text { pational risks resulting from the } \\
\text { unhealthy environment at work. }\end{array}$ \\
\hline
\end{tabular}

The socioeconomic characteristics are mentioned in most of the studies analysed. The level of education is indicated in 12 (70.5\%) articles; of these, 11 (92\%) refer that the level of education of informal workers is low, ranging from illiteracy to basic education. Only one (8\%) study mentions that there are graduate workers or workers with complete secondary education among the research subjects.

The average monthly income of informal workers is identified in 11 (65\%) articles, and seven of these (64\%) reported that the professionals received the equivalent to one minimum wage or less in current Brazilian reais (R\$), around US\$330,97. Four (36\%) studies reported that the workers earned up to two minimum wages in current Brazilian reais, i.e. approximately US\$661,94.

The working hours were mentioned in 13 (76.4\%) of the analysed articles. Of these, six (46\%) articles reported that the study subjects worked between 40 and 50 hours per week, and four (31\%) mentioned that informal professionals worked around 50 hours per week or more, with the possibility of working up to 80 hours per week. Two (15.5\%) articles mentioned that the study subjects worked around 30-40 hours per week, and only one (7.5\%) study reported a workload of around 30 hours per week or less.

It should be underlined that most studies were conducted in developing countries, which indicates 
that informal work affects predominantly the poorest countries and is related with the social inequalities and the environmental and economic conditions of a given population, thus interfering with the health conditions of these individuals. The studies conducted by Almeida et al. (2009), Jaimes and Amaya (2013) and Prosenewicz and Lippi (2012) reported that the informal workers who participated in the study were in a situation of vulnerability, since they were faced with poor basic sanitation conditions and difficulties in the access to health services, and developed their activities in unhealthy work environments with limited health conditions. Díaz et al. (2010) also described, as a result of their study, the sociodemographic characteristics of coal miners in Paipa, Colombia, and referred that such characteristics are compatible with extreme poverty.

As regards the time limit, we observed that this topic was not explored by the scientific community between 1990 and 2001, which suggests that perhaps the theme was still very recent in the 1990s for any conclusion to be drawn on the health of informal workers. This phenomenon in the job market was gradually taking shape as a result of the structural and economic changes that occurred in this period. However, this profile slowly began to change in the following year (2002), in which one article was published on the theme. We can observe that from 2009 onwards the interest in the health of informal workers increased, with the publication of 12 articles, which suggests a more recent interest in the academic realm on the matter in question. The last two articles were published in 2013.

Of the studies analysed, we found a prevalence of osteomuscular problems in informal workers. Such problems are translated into complaints such as low back pain, neck, leg and knee pain, tendinitis, and extreme physical fatigue. These conditions may be related with an exhausting type of work that requires excessive physical effort and repetitive movements and is characterised by long working days that may reach 60 or more hours per week. The studies of Alencar et al. (2009); Ballesteros et al. (2012); Gangopadhyay and Das (2012); Lakhani (2004); Rosa and Matos (2010) explored this issue.

The fact that the informal worker has no social or labour rights contributes to job exploitation and insecurity. The study conducted by Vigil et al. (2007) reports that the manual carriers of load handled bags of $150 \mathrm{Kg}$ and could move from 10 to 20 tonnes on a daily basis, demonstrating that the weight limit is not regulated in any rules, laws or decrees that could protect the health of these workers.

Despite being in a smaller percentage, but of great relevance in the field of worker's health, psychological disorders were also identified among the informal workers. Reflecting on this finding, we can state that the lack of labour rights corroborates with the depreciation of the informal worker's mental health. The fact that these workers who perform their functions deliberately have no fixed income makes them work longer hours, since the more hours invested at work, the greater the possibility of increasing the monthly income. In turn, the monthly income is considered low, ranging from one minimum wage or less to a maximum of two wages. In this context, the inability to fully support the family, even after having to perform dangerous and exhausting tasks, generates a feeling of uselessness and depression in the worker, which contributes to the development of mental disorders that result in poor living conditions (Gangopadhyay \& Das, 2012; Lakhani, 2004).

The limitations of this study were the lack of cohort studies, which could assess the results of this exposure over time, as well as the low number of publications addressing the topic.

\section{Conclusion}

The study achieved its initial objective: To describe, through scientific articles, the implications of informal work for the health of workers employed in this sector of the economy.

We concluded that these subjects are subjected to unhealthy working conditions, low wages and long working days, which trigger mental and physical morbidities. These aspects were observed in different parts of the world, including Latin America, India, Honduras or the USA.

Therefore, through this study it was possible to understand that there is a strong association between health and the professional activity performed by the individual. Work often becomes the activity at which informal workers spend most of their day, which may represent 16 hours in a single day.

Thus, when addressing the health of informal 
workers, one cannot ignore the work process, the characterisation of the activities performed and the type of exposure to which these workers are subjected. Not to mention the risks inherent to the work environment, such as accidents and ergonomic, physical, chemical or biological risks which negatively influence the workers' health.

In this context, it is important to highlight that the informal workers have no legal support available in their professional activities, and, therefore, are not included in programs aimed at the promotion and preservation of health by means of the early detection of work-related health problems or occupational diseases. Such individuals are left abandoned, at the mercy of their luck. They wish not fall ill so that they can continue to support their families, even if that is not enough to meet all their needs.

By reflecting on the results of this study, we have learned that the informal workers are in situations of social vulnerability, and that strategic changes are needed to ensure these workers' access to health care, thus preventing them from being excluded from the right to health as a result of their form of insertion in the job market. Public policies should take into account the safety and health of informal workers, giving greater visibility to a social activity which has not been given a central place and whose health-related risks have not been investigated and identified.

Although there are informal workers in different countries worldwide, particularly in the poorest countries, as shown in the results of this study, there are only a few studies addressing informal work and its aspects from the perspective of occupational health. We believe that the identification of the working conditions of the individuals in the informal economy, as well as its repercussions for the workers' health provides us a basis for understanding their social context and finding better possibilities for care provision as health professionals.

Thus, at the level of health care, this study suggests the creation of alternate schedules in health services to care for informal workers, in an attempt not to exclude them from the right to health, broadening equitable access to health. It also proposes the integration into the health professionals' practice of the identification and registration of the work situation and profession of the users in the health care units and services with a view to maximising the early detection of the association between the profession and the health problem of the user for the purposes of diagnosis and reporting of work-related health problems.

In the area of education, this study contributes to the promotion of academic discussions about this theme, increasing the knowledge of students and teachers in these spaces of exchange. It also encourages the creation of work groups aimed at investigating the health status and possible events related to the activities developed by informal workers, awakening the critical view about the different dimensions and circumstances involving the provision of care to the worker.

Finally, this study demonstrates the need to perform field research to characterise the health and working conditions of a significant percentage of the population of workers, supporting reflections and proposals that result in better ways to ensure the access to health care to those who, despite developing their professional activities in informal situations, are citizens by law.

\section{References}

Alencar, M. C., Cardoso, C. C., \& Antunes, M. C. (2009). Condições de trabalho e sintomas relacionados à saúde de catadores de materiais recicláveis em Curitiba. Revista de Terapia Ocupacional da Universidade de São Paulo, 20(1), 36-42. Retrieved from http://pesquisa.bvsalud.org/portal/resource/ pt/lil-657211

Almeida, J. R., Elias, E. T., Magalhães, M., \& Vieira, A. J. (2009). Efeito da idade sobre a qualidade de vida e saúde dos catadores de materiais recicláveis de uma associação em Governador Valadares, Minas Gerais Brasil. Ciências e Saúde Coletiva, 14(6), 2169-2180. Retrieved from http://www. scielo.br/scielo.php?script $=$ sci_pdf $=\$ 141381232009000$ $600024 \& \operatorname{lng}=\mathrm{en} \& \mathrm{nrm}=\mathrm{iso \& t \operatorname {lng }}=\mathrm{pt}$

Ballesteros, V. L., Arango, Y. L., \& Urrega, Y. M. (2012). Condiciones de salud y de trabajo informal en recuperadores ambientales del área rural de Medellín, Colombia, 2008. Revista de Saúde Coletiva, 46(5), 866-874. Retrieved from http://pesquisa. bvsalud.org/dss/resources/lil-655039

Costa, M. S. (2010). Trabalho informal: Um problema estrutural básico no entendimento das desigualdades na sociedade brasileira. Caderno CRH, 33(58), 171-190. Retrieved from http://www.scielo.br/scielo.php?pid=S010349792010000100011\&script $=$ sci_arttext 
Díaz, J. M., Abril, F. G., \& Garzón, J. A. (2010). Salud y trabajo: Minería artesanal del carbón en Paipa, Colombia. Avances em Enfermería, 28(1), 107-115. Retrieved from http://bases. bireme.br/cgibin/wxislind.exe/iah/online/?IsisScript =iah/ iah. $x i s \& s r c=$ google\&base $=$ LILACS\&lang $=p \&$ nextAnextA $=\operatorname{lnk} \&$ exprSearch $=561944 \&$ indexSearch $=$ ID

Gangopadhyay, S., \& Das, T. (2012). An ergonomic study on the onset of mental fatigue among the load handling workers of a central market area in Kolkata. Work: A Journal of Prevention, Assessment and Rebabilitation, 41(0), 24672471. Retrieved from http://pesquisa.bvsalud.org/portal/?0 utput $=$ site\&lang $=\mathrm{pt} \&$ from $=0 \&$ sort $=\&$ format $=$ summar $\mathrm{y} \& \operatorname{cococ}=20 \& \mathrm{fb}=\&$ page $=1 \&$ filter $\% 5 \mathrm{Bdb} \% 5 \mathrm{D} \% 5 \mathrm{~B} \% 5 \mathrm{D}=$ LILACS\&q $=$ An + ergonomic + study + on + the + onset + of + mental + fatigue + among + the + load + handling + worke $\mathrm{rs}+$ of $+\mathrm{a}+$ central + market + area $+\mathrm{ii}+$ Kolkata\&index $=\mathrm{ti}$ \&search_form_submit $=$ Pesquisar

Jaimes, C. P., \& Amaya, R. M. (2013). Condiciones de salud y laborales de la población trabajadora informal en situación de desplazamiento de Bucaramanga, Colombia. Investigaciones Andina, 15(26), 628-639. Retrieved from http://pesquisa. bvsalud.org/portal/resource/pt/iil-673613. doi: 10.3233/ WOR-2012-0482-246

Krein, J. D., Cardoso, J. C., Biavaschi, M. B., \& Teixeira, M. L. (2013). Regulação do trabalbo e instituições públicas. São Paulo, Brasil: Fundação Perseu Abramo.

Lakhani, R. (2004). Occupational health of women construction workers in the unorganised sector. Journal of Health Management, 6(2), 187-200. Retrieved from http:// jhm.sagepub.com/content/6/2/187.full.pdf. doi: $10.1177 / 0972063404006002$

Matsuo, M. (2009). Trabalho informal e desemprego: Desigualdades sociais (PhD Thesis). Retrieved from http:// www.teses.usp.br/teses/disponiveis/8/8132/.../MYRIAN_ MATSUO.pdf

Milían, L. C., Rivera, M. F., \& Chévez, F. M., (2011). Pobreza, salud y trabajo em cultivadores de tabaco en el valle de jamastrán, el paraíso, Honduras. Rev. Med Hondur, 79, (4), 191-196. Retrieved from http://www.bvs.hn/RMH/pdf/2011/pdf/ Vol79-4-2011-5.pdf

Organización Internacional del Trabajo, Oficina Regional de la OIT para América Latina y el Caribe. (2013a). En américa latina y el caribe hay 127 millones trabajadores em la informalidad. Lima, Perú: Autor.
Organización Internacional del Trabajo, Informe preparado por la Oficina Regional de la OIT para América Latina y el Caribe. (2013b). La OIT em américa latina y caribe: Avances y perspectivas. Lima, Perú: Autor.

Porto, M. F. S.; Juncá, D. C. M.; Gonçalves, R. S \& Filhote, M.I. F. (2004). Lixo, trabalho e saúde: um estudo de caso com catadores em um aterro metropolitano no Rio de Janeiro, Brasil. Caderno Saúde Pública, 20 (6), 1503-1514. Retrieved from http://www.scielo.br/scielo. php? script $=$ sci_nlinks\&ref $=000185 \&$ pid $=$ S0102 $7182200600020000900023 \& \operatorname{lng}=p t$

Prazeres, T. J., \& Navarro, V. L. (2011). Na costura do sapato, o desmanche das operárias: estudo das condições de trabalho e saúde das pespontadeiras da indústria de calçados de Franca, São Paulo, Brasil. Cad. Saúde Pública, 27(10),1930-1938. Retrieved from http://www.scielo.br/pdf/csp/v27n10/06.pdf

Prosenewicz, I., \& Lippi, U. G. (2012). Acesso aos serviços de saúde, condições de saúde e exposição aos fatores de risco: Percepção dos pescadores ribeirinhos do Rio Machado de Ji-Paraná, RO. Saúde Sociedade, 21(1), 219-31. Retrieved from http://www.scielo.br/scielo.php?script $=$ sci pdf\&pid $=$ S0104-12902012000100021\&lng $=$ en\&nrm $=$ iso $\& \operatorname{lng}=\mathrm{pt}$

Rosa, M. F., \& Matos, U. A. (2010). A saúde e os riscos dos pescadores e catadores de caranguejo da Baía de Guanabara. Ciências e Saúde Coletiva, 15(1), 1543-1552. Retrieved from http://pesquisa.bvsalud.org/portal/resource/pt/lil-555689

Santos, M. A., \& Hormanez, M. (2013). Atitude frente à morte em profissionais e estudantes de enfermagem: Revisão da produção científica da última década. Ciência e Saúde Coletiva, 18(9), 2757-2768. Retrieved from http://www.scielo. br/scielo.php?pid $=$ S1413-81232013000900031\&script $=$ sci arttext

Sobral, A., \& Freitas, C. M. (2010). Modelo de organização de indicadores para operacionalização dos determinantes socioambientais da saúde. Saúde e Sociedade, 19(1), 35-47. Retrieved from http://www.scielo.br/scielo.php?script =sci pdf\&pid $=$ S0104-12902010000100004\&lng $=$ en\&nrm $=$ iso $\& \operatorname{lng}=\mathrm{pt}$

Vigil, L., Gutiérrez, R., Cáceres, E., Collantes, H., \& Beas, J. (2007). Salud ocupacional del trabajo de estiba: Los trabajadores de mercados mayoristas de Huancayo. Revista Peruana de Medicina Experimental y Salud Publica, 24(4), 336342. Retrieved from http://www.scielo.org.pe/scielo. php?script $=$ sci_pdf\&pid $=$ S1726-46342007000400003\&lng $=$ es\&nrm $=$ iso\&tlng $=$ es 
